\title{
Linguocultural approach as means of managing learning strategies when teaching a foreign language
}

\author{
Anastasia Sinichkina $^{1}$, Lilya Faizrahmanova $^{1}$, and Rezeda Muhtarova ${ }^{1^{*}}$ \\ ${ }^{1}$ Department of Romano-Germanic languages and Methods of Teaching them Naberezhnye Chelny \\ State Pedagogical University, Naberezhnye Chelny, Russia
}

\begin{abstract}
The article deals with the survey conducted upon the basis of the Pedagogical University with the students learning English as a foreign language. The study is aimed at finding the correlation between applying the linguocultural approach and improving students' leaning strategies implication. Thus, the study defined the positive impact of the linguocultural approach upon the frequency of learning strategies usage by the students. The study deals with such types of learning strategies as common, metacognitive, affective, and social strategies implemented by the students learning English grammar and phonetics. The authors of the article used a questionnaire method to assert the fact that linguocultural approach has positive impact upon the development of the students' learning strategies depending upon their gender and national peculiarities.
\end{abstract}

\section{Introduction}

Technological and informational progress, the expansion of international borders, social and academic mobility, undoubtedly, bring radical changes in the process of education at its different levels. In accordance with the Russian methodologists' N.D. Galskova and N.I. Gez opinion, language education is based on an intercultural paradigm and acts as a tool for the creative development of a socially active and independent person [1].

In fact, the aspect of culture in teaching foreign languages ceases to be a meaningful element, representing scattered fragments of information about the country of the language being studied. Learning a foreign language in the professional sphere is not aimed at shaping certain skills and developing the language skills of students, but on the formation of student's personality, able to use a language to represent the identity of his culture, ready for intercultural communication and interaction in the target foreign language and ready to apply these skills in professional activity [2], [3], [4], [5], [6]. Based on the communicative paradigm, the content component of the learning process is represented by real communication situations, the use of authentic audio and video materials, and the conduct of relevant events [7], [8]. Observing these conditions, the student is immersed in the culture of the language being studied.

\footnotetext{
* Corresponding author: rezedamuh@gmail.com
} 
In the process of teaching a foreign language, there are various approaches to solve this problem, a modular approach, a metasubject approach, an integrative approach, a linguocultural approach, and others.

\section{Materials and methods}

The necessity of considering the culture of the studied language using linguocultural approach is grounded in the works of such authors as P. V. Sysoev [9], O. V. Gukalenko, M. A. Suvorova, I. A. Martyanova, Manabaeva Zh., R. Y. Zakirov. S. H. A. A. Sagintaeva Tilenbaev, Z. M. Mangileva.

Despite the wide coverage of the issue, it is worth noting that the problem of introducing the linguocultural component and the problem of including foreign language culture in foreign language training remain relevant.

In accordance with this approach to teaching a foreign language, there is a need to integrate such aspects of learning a foreign language as grammar, phonetics, as well as, integrate some technologies and detect effective learning strategies.

We consider teaching a foreign language in the framework of the linguocultural approach as a way to combine different aspects of the language to achieve better academic results [10].

The purpose of this research is to study the effectiveness of the linguocultural approach as a means to manage learning strategies when teaching grammar and phonetics in foreign language classes in a pedagogical university.

The research methods include the methods of analysis and synthesis, statistical method the pilot training and questionnaire method.

To determine the effectiveness of a series of exercises, tasks and methods, experimental and practical work was carried out. Before and after completing the exercises and tasks, students were asked questions about the learning strategies they used, which include cognitive, metacognitive, social and affective strategies.

Teaching a foreign language, it is important to maintain a balance between literacy and phonetic correctness of speech, based on the correct usage of the grammatical structures and the pronunciation norms of the language, and the absence of a linguistic barrier. It is obvious that students, who try to comply with the norms of grammar, lose fluency and phonetic correctness while speaking [11].

R.L. Oxford defines learning as specific actions taken by the learner to make learning easier, faster, more enjoyable, his ability to apply these actions to new situations [12].

The study considers the following learning strategies: metacognitive, affective, and social. They can be useful for all four language skills: listening, reading, speaking, and writing [13].

Metacognitive strategies are methodological strategies used to control, regulate, or study a language. Students' knowledge of various aspects of language learning determines their choice of strategies [14].

Language learners can gain control over the language through affective strategies. Affective strategies fall into three groups: reducing anxiety, encouragement, and controlling emotions. Affective strategies can be one of the most successful factors for language learners [13].

Social strategies. According to R. L. Oxford [12], language is a form of social behavior and communication. Communication can only take place between people. Thus, social strategies are very important. Social strategies are divided into three groups: the ability to ask questions, collaborate with others, and empathize with others [13]. 


\section{Results and discussions}

Grammar skills along with phonetic skills are considered necessary elements of a successful speaking and communication process.

The linguocultural approach should perform five functions: developmental, educational, academic, cognitive and professional. Teaching a foreign language within the framework of the linguocultural approach can be defined as a joint activity of the teacher and students, when the first transfers knowledge, skills and abilities to the students (training), and the second assimilates this knowledge, skills and abilities (teaching); as a social process determined by the needs of society's development, the process of gaining social, socioeconomic experience [15].

Within the framework of this study students were offered a series of exercises and tasks to develop their grammatical skills. The use of the linguocultural approach seems appropriate at the system-synthesizing stage.

Here are some examples of exercises:

Ex.1. Read the text. Fill in the gaps using appropriate grammatical forms. Explain the use. Tell about the landmark in London using correct word-forms:

Everyone __ (hear) about the tower of Big Ben at least once. This (to be) a great attraction and pride of Londoners. Every year thousands of travelers from all over the world (come) together to admire this wonder-creation.

Big Ben is ___ (big) bell of Westminster Palace. A lot of people think that Big Ben is the tower in London, but in fact it is a 13 tones bell inside the clock.

The official name of the tower in which Big Ben is located___ (to be) originally the Clock Tower; it ___ (to be) renamed Elizabeth Tower in 2012 to mark the Diamond Jubilee of Elizabeth II, Queen of the United Kingdom. Despite the other names, Big Ben still (stay) the most popular one.

This watch may (name) after the first technical committee, Benjamin Hall. However, some sources say that ringtones boxing champ Benjamin Coant.

Ex.2. Listen to two different records on the British Council Kids 1) https://learnenglishkids.britishcouncil.org/ru/video-zone/syrian-refugee-family and

2) https://learnenglishkids.britishcouncil.org/ru/video-zone/mr-tumbles-christmas-fairy.

Define the tenses used in the videos. Explain the choice. What new things about culture have you learned, tell the others what you have learned.

Ex.3 Make up an imaginary cartoon hero that will represent your country (or Great Britain), draw its picture, describe it using adjectives in different forms.

Along with the formed grammatical skills, phonetic skills are an important condition for successful communication, a way to overcome the language barrier, as well as a means of increasing internal motivation and confidence [16]. For any teacher, competent and expressive oral speech is an important professional quality. This is especially important for a foreign language teacher.

In the process of formation and developing phonetic skills along with the tasks of receptive and reproductive character students take part in discussions on cultural issues, conduct analytical work on audios and texts and videos, collect additional information about cultural peculiarities of a specific language, phonetic features of the speech of the representatives of the target culture, voice the characters of the famous authentic animations and movies [17], [18], [19].

The linguocultural approach at the introductory and preparatory stage is implemented in the work on examples of oral folk art of the studied culture: tongue twisters, proverbs, limericks. Students are to find equivalents of proverbs in their native language, to intone, transcribe, and conduct a comparative analysis of the intonation design of proverbs in their 
native and studied language. Students are to fulfill the following tasks: 1) Listen (underline) the sounds similar to/different from your native language; 2) Compare the intonation in these questions with those of your native language, etc.

At the standardizing stage, the linguocultural approach can be used when working on the following phonetic material: texts of different intonation styles, song material, film extracts. The following tasks can be offered: 1) Find out the peculiarities of the intonation style and compare them with those of your native language; 2) Write down and intone the commands of an English teacher and compare them with those of your native language teacher; 3) What cultural feature have you found out while watching (listening)? 4) What phonetic peculiarities have you noticed? 5) What phonetic means helped the speaker to express the definite attitude to the situation?

At the final or system-synthesizing stage, the improvement of phonetic skills acquires a systematic character, which is based on the formation of the ability of dialogic and monological speech using phonetic means of speech expressiveness. Tasks for independent prosodic solution of communicative tasks with the use of stylistic variation of intonation and phonetic means will be effective: situational and role-playing games, creative tasks, recitation of passages of prose or poetry. The linguocultural approach at this stage is used to help students form: a possible speech portrait of the personality of an English speaker; attitude to the culture of the studied language, to its literary values; readiness to overcome the language barrier associated with the phonetic features of the speech of representatives of the studied culture; readiness to recognize and perceive various accents [20]. The goal is achieved through:1) the analysis of phonetic features of oral speech of people of different age groups, social status and gender in different language situations; 2) analysis of intonation styles of the language being studied; 3) analysis of the features of fast/slow speech; 4) analysis of the speeches by famous political figures and artists. The content component can be represented by the following thematic sections: "English as an International Language", "English Accents", "Fast and Slow Speech", "Intonation Styles", "Fixed Phrases and Idioms in Speech Units", etc.

The phonetic material at this stage is not only a prepared authentic speech presented by professional speakers, but also oral speech of native speakers, presented by people of different age groups, gender backgrounds, etc. In an artificial language environment, students work with audio and video material, films, songs, and authentic Internet resources. The following tasks will be effective: 1) Listen to the speakers in different English accents. Write brief notes about what they say (Where do you think they are from?); 2) Listen. Write the number of words you here in each speech; 3) Listen to the sentence with fixed phrases and idioms. Underline the last prominent syllable in each.

Consider the statistics describing the results of the pilot training.

86 students completed the survey. Students were asked to complete the test and the questionnaire on the study of foreign language learning strategies on the Likert scale [12]. Students performed testing and questionnaires before and after the series of lessons. According to the results of the calculations, cognitive strategies were used most often in the learning process, and social and affective strategies were used second in frequency. After a series of classes, students showed an increase in the role of metacognitive and cognitive mechanisms, as well as social/ affective mechanisms, respectively, by $0.8 \%, 1.2 \%$ and $2.6 \%$. The results of the study clearly show the advantages of using a linguocultural approach in teaching grammar and phonetics. Moreover, this approach helps to increase motivation to learn, making the process more entertaining.

This study considers the influence of the linguocultural approach on foreign language learning strategies as a way to improve the effectiveness of learning during a two months' period. Students were offered different types of tasks: comparative analysis of phonetic features of the native and studied languages; phonetic analysis of authentic video extracts 
viewed; voice acting; creative and project tasks; recitation of prose and poetry fragments, etc. authentic tasks, a system of language and communication exercises. The study was conducted for students of the first and second courses of study getting a degree in "Pedagogical education" (with two training profiles), profiles "Foreign language and Second foreign Language" in classes on the Practice of oral and written speech of the first foreign language, Practical grammar and Practical Phonetics.

Students were interviewed by means of a questionnaire to study strategies in teaching grammar, phonetics and speaking, the questionnaire included 43 questions. Some questions were adjusted to check the use of strategies in teaching different aspects of the language. Some questions concerned the learning strategies used by students. The purpose of the survey was to investigate the following items:

1) the influence of the linguocultural approach on the learning strategies in grammar, phonetics and speaking

2) grammar and speech learning strategies that students use in the initial training courses;

3) differences in the use of the strategy by male and female students;

4) differences in the learning strategies of students belonging to different nationalities and cultures.

The study provides the validity and reliability of tools for collecting information and conclusions of the study.

15 minutes were allocated for the questionnaire. The questionnaire was organized in such a way that the final scale of agreement-disagreement was expressed in grades from " 1 "- never, " 2 " - rarely," 3 "- sometimes" 4 "- usually and" 5 " - always. The questionnaire was developed on the basis of the Oxford Learning Strategies [12], with adjustments taking into account different aspects of foreign language teaching. In each column, an average value of 1 to 5 is presented, which shows the strategies used by students at the preparatory and the controlling stages of the pilot training.

Table 1. The use of the learning strategies in teaching foreign language at the preparatory stage of the pilot training.

\begin{tabular}{|c|c|c|c|c|}
\hline Response & Always use learning strategies & Sometimes & Rarely & Never \\
\hline $\begin{array}{c}\text { Students' } \\
\text { assessment }\end{array}$ & 5 & 8 & 72 & 1 \\
\hline
\end{tabular}

Table 2. The use of the learning strategies in teaching foreign language at the controlling stage of the pilot training.

\begin{tabular}{|c|c|c|c|c|}
\hline Response & Always use learning strategies & Sometimes & Rarely & Never \\
\hline $\begin{array}{c}\text { Students' } \\
\text { assessment }\end{array}$ & 22 & 34 & 24 & 0 \\
\hline
\end{tabular}

According to statistics, first-and second-year students rarely use foreign language learning strategies, their learning is neither organized nor systematic, and the use of learning strategies is rather chaotic. The use of cognitive strategies prevails over social and affective ones.

Table 3. The types of the learning strategies in teaching foreign language at the preparatory stage of the pilot training.

\begin{tabular}{|c|c|c|c|c|}
\hline $\begin{array}{c}\text { The type of the } \\
\text { strategy }\end{array}$ & $\begin{array}{c}\text { Common } \\
\text { strategy }\end{array}$ & $\begin{array}{c}\text { Cognitive } \\
\text { strategy }\end{array}$ & $\begin{array}{c}\text { Meta-cognitive } \\
\text { strategy }\end{array}$ & $\begin{array}{c}\text { Social / affective } \\
\text { strategy }\end{array}$ \\
\hline Median value & 2,991 & 3,377 & 3,005 & 2,763 \\
\hline
\end{tabular}


In general, the questionnaire showed that students are able to analyze and apply certain methods of organizing the process of learning a foreign language, they have wellestablished skills to work with sources, dictionaries and other reference materials, but there is no mechanism for working on the language in cooperation. After carrying out the work within the framework of the linguocultural approach, there is an increase in the activity of both cognitive and social and affective strategies. Thus, learning a language becomes more conscious.

Table 4. The types of the learning strategies in teaching foreign language at the controlling stage of the pilot training.

\begin{tabular}{|c|c|c|c|c|}
\hline $\begin{array}{c}\text { The type of the } \\
\text { strategy }\end{array}$ & $\begin{array}{c}\text { Common } \\
\text { strategy }\end{array}$ & $\begin{array}{c}\text { Cognitive } \\
\text { strategy }\end{array}$ & $\begin{array}{c}\text { Meta-cognitive } \\
\text { strategy }\end{array}$ & $\begin{array}{c}\text { Social / affective } \\
\text { strategy }\end{array}$ \\
\hline Median value & 3,005 & 3,482 & 3,128 & 2,978 \\
\hline
\end{tabular}

The study of the gender factor in the use of strategies before and after the use of the linguocultural approach did not show any significant results. There is a slight increase in the use of cognitive strategies by male students $(0.87 \%)$. As for students of different nationalities and cultures, the pilot training has led to quite interesting results. Students from Turkmenistan who have difficulty learning a foreign language, especially grammar and phonetics, have become more likely to use cognitive and social/affective strategies.

Table 5. The use of learning strategies by the representatives of Russia (R) and Turkmenistan (T) at the preparatory stage of the pilot training.

\begin{tabular}{|c|c|c|c|c|c|c|c|c|}
\hline $\begin{array}{c}\text { The type of the } \\
\text { strategy }\end{array}$ & \multicolumn{2}{|c|}{$\begin{array}{c}\text { Common } \\
\text { strategy }\end{array}$} & \multicolumn{2}{c|}{$\begin{array}{c}\text { Cognitive } \\
\text { strategy }\end{array}$} & \multicolumn{2}{c|}{$\begin{array}{c}\text { Meta-cognitive } \\
\text { strategy }\end{array}$} & \multicolumn{2}{c|}{$\begin{array}{c}\text { Social / affective } \\
\text { strategy }\end{array}$} \\
\hline $\begin{array}{c}\text { (Russia/ } \\
\text { Turkmenistan) }\end{array}$ & $\mathrm{R}$ & $\mathrm{T}$ & $\mathrm{R}$ & $\mathrm{T}$ & $\mathrm{R}$ & $\mathrm{T}$ & $\mathrm{R}$ & $\mathrm{T}$ \\
\hline Median value & 2,998 & 2,003 & 3,321 & 3,298 & 3,003 & 2,978 & 2,654 & 1,839 \\
\hline
\end{tabular}

Table 6. The use of learning strategies by the representatives of Russia (R) and Turkmenistan (T) at the controlling stage of the pilot training.

\begin{tabular}{|c|c|c|c|c|c|c|c|c|}
\hline $\begin{array}{c}\text { The type of the } \\
\text { strategy }\end{array}$ & \multicolumn{2}{|c|}{$\begin{array}{c}\text { Common } \\
\text { strategy }\end{array}$} & \multicolumn{2}{c|}{$\begin{array}{c}\text { Cognitive } \\
\text { strategy }\end{array}$} & \multicolumn{2}{c|}{$\begin{array}{c}\text { Meta-cognitive } \\
\text { strategy }\end{array}$} & \multicolumn{2}{c|}{$\begin{array}{c}\text { Social / affective } \\
\text { strategy }\end{array}$} \\
\hline (Russia/Turkmenistan) & $\mathrm{R}$ & $\mathrm{T}$ & $\mathrm{R}$ & $\mathrm{T}$ & $\mathrm{R}$ & $\mathrm{T}$ & $\mathrm{R}$ & $\mathrm{T}$ \\
\hline Median value & 3,001 & 2,983 & 3,321 & 3,318 & 3,107 & 3,009 & 2,754 & 2,026 \\
\hline
\end{tabular}

The results of the study showed that teaching a foreign language using a linguocultural approach contributes to increasing motivation and activation of unused learning strategies by students. Especially significant is the growing interest of Turkmen students in new forms of work in the classroom, which is important for overcoming difficulties when working with foreign citizens. The linguocultural approach did not show much difference when used by students of different genders.

\section{Conclusion}

Thus, this study showed that the use of a linguocultural approach in teaching a foreign language in classes on Practical grammar, Practical phonetics, Practice of oral and written speech of the first foreign language gave definite results. The students began to resort more frequently to the use of learning strategies. Thus, the use of cognitive and meta-cognitive strategies increased by 0.89 and $0.72 \%$, respectively. The use of social / affective strategies increased by $0.86 \%$. The slight increase can be explained by a short period of using this 
approach - two months, in the future this experiment can be continued, as it showed good results, especially among the foreign students. It is obvious the motivation of students increases as well when using the linguocultural approach.

As a result, the study revealed the relationship between the use of the linguocultural approach and the use of various foreign language learning strategies, thereby increasing the effectiveness of the learning process.

\section{References}

1. N. D. Galskova, N. I. Gez, The theory of teaching a foreign language. Linguodidactics and methodics. Manual for students of higher education institutions, Moscow, Publishing center "Academy" (2013).

2. D. Johnson, R. Johnson, Learning together and alone, cooperation, competition, and individualization, Englewood Cliffs, NJ: Prentice-Hall (1975).

3. D. Johnson, R. Johnson, Learning together and alone, cooperative, competitive, and individualistic learning, Needham Heights, MA: Prentice-Hall (1994).

4. B. Harrison (ed.), Culture in the classroom. ELT Document 132, Modern English Publications, The British Council, 75-101 (1990).

5. M. Safina, Formation of Socio-Cultural Competence in Foreign Language Teaching. Procedia - Social and Behavioral Sciences 136, 80 - 83 (2013).

6. V. V. Safonova, Studying the language of International communication in the context of culture and civilization dialogue, Voronezh, Istoki (1996).

7. K. A. Abulhanova, T. N. Berezin, Time of personality and time of life. SaintPetersburg: Aleteya, (2001).

8. O. Shipunova, I. Berezovskaya, E. Gashkova, T. Ivanova, The boundaries of semantic barriers in intercultural communication, 4th International Multidisciplinary Scientific Conference on Social Sciences and Arts SGEM2017, Conference Proceedings Book2, 371-378, 1 (2017).

9. P.V. Sysoev, Language and culture: in the search of the new approach to teaching foreign languages, Foreign languages at school, 17-23, 4 (2001).

10. S. A. Radionova, A. A. Sinichkina, E.B. Tsyganova, Grammar Skills Development At Lessons Of German As A Second Foreign Language. Proceedings of the 11th International Conference on Education and Educational Psychology (ICEEPSY 2020), 65-71 (2020). https://dx.doi.org/10.15405/epiceepsy.26728141.20111.1

11. R. Mukhtarova, E. Tsyganova, Benefits of Student-centered Methods in Teaching Theoretical Grammar, Modern Journal of Language Teaching Methods, 12, 846-853 (2018).

12. R. L. Oxford, Language Learning Strategies: What Every Teacher Should Know, New York: Newbury House Publishers (1990).

13. Y. Tilfarlioglu, An Analysis of the Relationship between the Use of Grammar Learning Strategies and Student Achievement at English Preparatory Classes, Journal of Language and Linguistic Studies, 2 (2005). - Retrieved from https://www.jlls.org/index.php/jlls/article/view/13

14. A. V. Falkovskaya, E. K. Mukhamedzyanova, O. N. Goryacheva, A. V. Potanina, Memonics efficiency in language practice, Revista San Gregorio, 25, Special Edition, 69-74 (2018). 
15. O. V. Naumova, Culturological aspect as a basis for the formation of foreign language culture, Moscow (2011). - Retrieved from https://ilingran.ru/library/sborniki/for_lang/2011_03/18.pdf

16. A. A. Sinichkina, Developing socio-cultural competence of university students on basis of interactive technologies, The European Proceedings of Social and Behavioural Science, 914-921 (2018). https://dx.doi.org/10.15405/epsbs.2018.12.02.99

17. L. M. Faizrahmanova, The specifics of the formation of phonetic skills of students in the conditions of multicultural educational space. Theoretical and methodological support of modern philological education in the light of the requirements of professional standards. Materials of the all-Russian scientific and practical conference. Naberezhnye Chelny: NSPU (2018).

18. J. Hanks, Exploratory practice in language teaching: puzzling about principles and practices. Palgrave Macmillan (2017).

19. J. H. Valdes (ed.), Culture Bound. Bridging the Cap in Language Teaching, Cambridge: Cambridge University Press (1986).

20. I. I. Golovchanskaya, Formation of phonostylistic competence of a foreign language teacher (bachelor's degree, French): dis. ... candidate of pedagogical Sciences, Moscow (2015). 